\title{
Pendampingan Peningkatan Nilai Jual Gedebok Pisang menjadi Bahan Olahan Pangan Kelompok Wanita Tani Suka Maju Kecamatan Kalikotes Klaten
}

\author{
Astuti Yuli Setyani ${ }^{1}$, Eka Adhi Wibowo ${ }^{2}$ \\ Program Studi Akuntansi, Fakultas Bisnis, Universitas Kristen Duta Wacana Yogyakarta \\ Email: ${ }^{1}$ astutiys@ @staff.ukdw.ac.id \\ ²ekaadhiw@staff.ukdw.ac.id
}

\begin{abstract}
Abstrak - Kelompok Wanita Suka Maju berdiri pada tahun 2007. Kelompok ini dibentuk dengan tujuan untuk meningkatkan kesejahteraan keluarga melalui kegiatan usaha para wanita desa Ngemplak, Kecamatan Kalikotes, Kabupaten Klaten. Daerah ini masih banyak warga mempunyai kebun cukup luas yang ditanami pohon pisang. Namun selama ini setiap panen pisang, pohon pisang hanya dibiarkan begitu saja bahkan dibuang. Apabila pohon pisang tersebut diolah menjadi makanan yang bernilai tinggi dan dapat dipasarkan atau dijual maka akan dapat menambah penghasilan ibu-ibu anggota kelompok Wanita Tani Suka Maju. Tujuan dari pengabdian ini memberikan motivasi kepada anggota kelompok dan memberi pelatihan dalam memanfaatkan limbah pohon pisang yang selama ini tidak dimanfaatkan menjadi bahan olahan pangan yang mempunyai nilai lebih. Rencananya, bagian pohon pisang yaitu pelepah pisang tersebut akan dibuat menjadi keripik. Pengolahan bahan yang selama ini menjadi limbah tentunya membutuhkan pelatihan dalam pengolahan, pengemasan dan pemasaran. Dengan adanya pengabdian ini berharap bisa menggerakkan minat berwirausaha terutama pada ibu-ibu kelompok Wanita Tani Suka Maju. Metode yang digunakan adalah pelatihan, pendampingan dan monitoring. Hasil dari pengabdian ini bahwa Kelompok Wanita Suka Maju dapat mengolah keripik pelepah pisang menjadi olahan pangan yang gurih, renyah dan enak. Pembuatan kemasan yang baik dan rapi agar penjualan meningkat dan dapat menambah penghasilan sehingga menjadi usaha baru bagi kelompok Wanita Tani Suka Maju.
\end{abstract}

Kata Kunci : Penguatan kelompok, pangan olahan, pemasaran, motivasi

Abstract - Kelompok Wanita Suka Maju (Suka Maju Women's Group) was established in 2007. This group was formed with the aim of improving the family welfare by doing the business activities for the woman in Ngemplak Village, Kalikotes,
Klaten, Indonesia. There are many banana plantations in this village. However, every time they finish harvesting the bananas, the banana trees are just thrown away. If the banana tree is processed into food, it will have a better value and can be marketed or sold, so that it will be able to increase the income of the people in the village. The purpose of this community service is to empower and motivate the members of Kelompok Wanita Suka Maju. The methods used are training, mentoring and monitoring. By doing this, it is hoped that the women in Kelompok Wanita Suka Maju have an interest in doing the entrepreneurship. The training programs in processing, packaging and marketing the banana trunk chips are very useful for these women. In creating the banana trees to make the savory, crunchy and delicious banana trunk chips, it requires certain special recipe. Making good, neat and attractive packaging for the banana trunk chips will also become one of the training programs. By using an attractive packaging, it is hoped that it will be able to increase its competitiveness in the market and increase the number of the sales. Furthermore, this community service program is expected to become a new business for empowering the members of Kelompok Wanita Suka Maju.

Keywords: Women Empowerment, processed food, motivation, marketing,

\section{PENDAHULUAN}

Kelompok Wanita Suka Maju berdiri pada tahun 2007. Kelompok ini dibentuk dengan tujuan untuk meningkatkan kesejahteraan keluarga melalui kegaiatan usaha para wanita desa Ngemplak, Kecamatan Kalikotes, Kabupaten Klaten. Peningkatan kesejahteraan ini dilakukan dengan menambah pengetahuan dan ketrampilan dalam hal memproses hasil panen menjadi lebih bernilai, yaitu berupa pangan olahan. Di daerah ini masih banyak kebun pisang 
yang kalau panen pisang pohonnya hanya dibuang tidak dimanfaatkan. Dengan banyaknya pohon atau batang pisang yang terbuang maka dengan pengabdian masyarakat ini akan dilakukan pendampingan dan pemberdayaan ibu-ibu kelompok Tani Suka Maju untuk bisa mengolah gedebok pisang ini menjadi olahan pangan yang mempunyai nilai jual yang cukup tinggi. Dibutuhkan ketrampilan dan keahlian dalam pengolahan gedebok pisang tersebut menjadi olahan pangan. Dengan ketrampilan ini maka wanita di desa Ngemplak dapat mengembangkan usaha kecil atau rumah tangga. Saat ini sudah ada beberapa usaha yang berjalan dan kedua kelompok ini akan mengembangkan produk olahan berbahan sayur sayuran hasil kebun yang diusahakan oleh sebagian anggota kelompok. Gedebok pisang akan diolah menjadi keripik gedebok pisang.

Tujuan dari pengabdian ini memberikan motivasi kepada anggota kelompok yang terkadang mengalami kelesuan dalam menjalankan usahnya. Sehingga dengan adanya pengabdian ini akan bisa menggerakkan lagi minat berwirausaha. Kewirausahaan merupakan kemampuan untuk melihat dan menilai peluang bisnis serta kemampuan mengoptimalkan sumber daya dan mengambil tindakan dan risiko dalam rangka mensukseskan bisnisnya ${ }^{[1]}$. Kelompok wanita Suka Maju ini diharapkan bisa mandiri dan menghasilkan pendapatan sendiri tanpa harus tergantung dari pendapatan suami dengan memproduksi keripik gedebok pisang.

Ketrampilan untuk produksi sudah dimiliki, namun masih perlu pengembangan karena dalam kelompok ini belum memiliki pengetahuan tentang cara pembuatan secara benar yaitu bagaimana mempertahankan gizi yang ada dalam gedebok pisang. Disamping itu, agar produk yang dihasilkan dapat memenuhi kebutuhan dan keinginan pasar maka diperlukan standarisasi produk yang berkaitan dengan kualitas dan kemasan yang bagus. Dengan peningkatan kualitas ini diharapkan kelompok ini bisa mendapatkan ijin P-IRT. Karena syarat P-IRT adalah pruduk yang mempunyai kualitas yang baik. Selain hal-hal tersebut diatas, masih dibutuhkan dorongan bagaimana menumbuhkan jiwa kewirausahaan atau menumbuhkan daya juang dalam pengembangan usaha yang telah dibentuk, untuk menjaga kelangsungan usaha, khususnya dalam menghadapi persaingan dan tantangan-tantangan eksternal lainnya

Bahan Baku yang melimpah dan belum dimanfaatkan dengan baik maka dengan baik maka dibutuhkan motivasi bagaimana keloompok wanita Tani Suka Maju bisa menambah penghasilan. Motivasi adalah sebuah dorongan, hasrat atau pun minat yang begitu besar di dalam diri, untuk mencapai suatu keinginan, cita-citra dan tujuan tertentu. Adanya motivasi akan membuat individu berusaha sekuat tenaga untuk mencapai yang diinginkannya.Seseorang yang memiliki motivasi tinggi akan memberikan dampak yang baik bagi kehidupannya ${ }^{[2]}$. Karena masih banyak ibu-ibu yang belum mempunyai pekerjaan atau penghasilan sendiri. Perlu pemberdayaan dan pendapingan dalam pengolahan gedebok pisang tersebut menjadi keripik yang tentunya mempertimbangkan rasa dan gizi. Dalam pembuatan tentunya dibutuhkan standar kualitas yang baik. Produk yang dihasilkan harus dikemas dengan baik dan menarik agar penjualan meningkat. Produk yang berkualitas tinggi artinya memiliki nilai yang lebih baik dibandinngkan dengan produk pesaing atau sering disebut produk plus. Setelah memahami arti kualitas, berikutnya dijelaskan mengapa kualitas produk merupakan fokus utama saat ini dalam suatu perusahaan ${ }^{[3]}$.

Dengan kemasan yang bagus akan menjadi oleh-oleh kas Klaten. Tentunya dalam pengabdian ini belum sampai pada pembuatan P-IRT dan diharapkan pengabdian selanjutnya dapat mewujutkan impian mendapatkan P-IRT dan mengubah kemasan menjadi lebih menarik. Dengan permasalahan yang ada maka diperlukan tambahan pengetahuan, dorongan dan pendampingan.

\section{RUMUSAN MASALAH}

Permasalahan yang dihadapi oleh Mitra kelompok wanita Suka Maju yang telah dibahas dalam diskusi antara tim pengabdi dari Fakultas Bisnis UKDW dan masyarakat di Klaten, dapat dirumuskan sebagai berikut :

1. Banyaknya bahan baku yang berupa batang pisang/gedebok pisang namun belum dimanfaatkan secara baik. Gedebok pisang bisa dibuat menjadi olahan pangan yang mempunyai nilai jual tinggi yaitu dengan diolah menjadi keripik gedebok pisang yang renyah dan gurih.

2. Peran kelompok Wanita Suka Maju belum dikembangkan dan diberdayakan secara optimal, sehingga manfaat dari berusaha secara kelompok belum dirasakan secara maksimal dan dibutuhkan motivasi.

3. Produksi produk makanan olahan dari kelompok mitra masih banyak keterbatasan, dalam pengolahan, kemasan dan pemasaran.

4. Pemasaran hasil produksi masih mengalami kesulitan karena terbatasnya pemahaman tentang strategi dan taktik pemasaran yang mencakup bauran pemasaran Dengan kegiatan ini diharapkan kelompok ini mendapatkan pengetahuan dan motivasi dalam pengembangan usahanya dan perbaikan kemasan produk.

\section{METODE PELAKSANAAN}

Berikut metode pelaksanaan yang digunakan pengabdi dalam pengabdian masyarakat ini: 
1. Penyuluhan menumbuhkan motivasi para anggota dilaksanakan bersama antara tim Pengabdi dan Mitra, yang akan dilakukan di Desa Ngemplak Kecamatan Kalikotes dengan nara sumber dari tim pengabdi, konsultan yang ahli dalam bidangnya, Dinas yang berkompeten dan masyarakat sekitar yang diperkirakan dapat bergabung dan memperkuat kolompok.

2. Praktek teknik produksi, pengemasan produk, bersama antara tim Pengabdi dan Mitra, yang akan dilakukan Desa Ngemplak Kecamatan Kalikotes dengan nara sumber dari tim pengabdi, pelatih yang ahli dalam bidangnya dan Dinas yang berkompeten.

3. Selama proses pengembangan kelompok dan pengelolaan produk, di buat catatan dan didokumentasikan untuk pembuatan profil kelompok usaha dan brosur sebagai media promosi, mengurus perizinan industri .

4. Pengembangan jejaring pemasaran dilakukan oleh tim pengabdi bersama mitra dengan menjalin hubungan melalui kontak langsung dengan konsumen potensial maupun menggunakan berbagai media, antara lain media elektronik, pameran, dsb.

5. Monitoring dilakukan antara pengabdi, mahasiswa dan para pemangku kepentingan yang dilakukan selama kunjungan lapangan maupun pertemuan kelompok. Pada akhir proyek (10 bulan) dilakukan evaluasi bersama. Evaluasi dipergunakan sebagai upaya perbaikan program dalam tahun-tahun mendatang.

\section{HASIL DAN PEMBAHASAN}

\section{A. Pelaksanaan Motivasi}

Motivasi adalah sebuah dorongan, hasrat atau pun minat yang begitu besar di dalam diri, untuk mencapai suatu keinginan, cita-citra dan tujuan tertentu ${ }^{[4]}$. Adanya motivasi akan membuat individu berusaha sekuat tenaga untuk mencapai yang diinginkannya. Seseorang yang memiliki motivasi tinggi akan memberikan dampak yang baik bagi kehidupannya. Tingginya motivasi tersebut akan mengubah perilakunya, untuk menggapai cita-cita dan menjalani hidup dengan lebih baik. Oleh karena itu, setiap orang sangat membutuhkan motivasi untuk dirinya sendiri. Hal ini, agar Anda tidak mudah putus asa dan merasa down. Serta dapat cepat bangkit saat mengalami kegagalan. Membuat seseorang menjadi berani mengembangkan usaha dan idenya melalui motivasi berwirausaha yang kuat. Motivasi adalah sesuatu yang dapat mempengaruhi atau mendorong seseorang yang merupakan energi pada diri seseorang untuk mencapai tujuan yang diharapkan ${ }^{[5]}$.

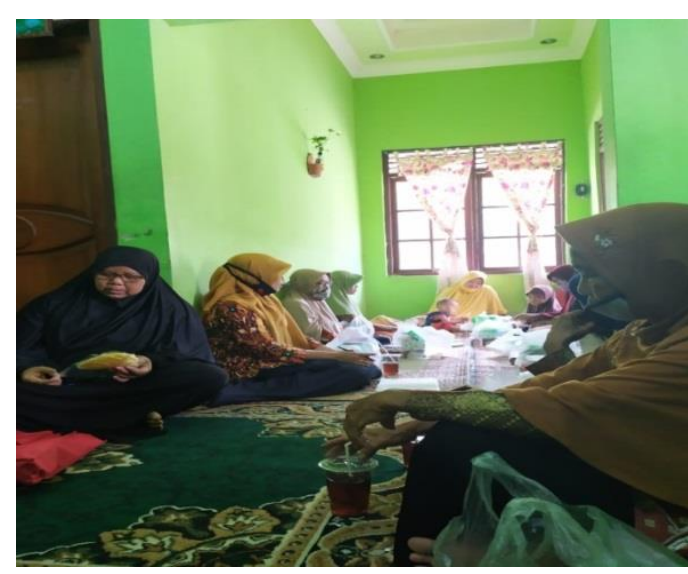

Gambar 1. Aktivitas Pemberian Motivasi

Motivasi dapat pula dikatakan serangkaian usaha untuk menyediakan kondisi-kondisi tertentu, sehingga seseorang itu mau dan ingin melakukan sesuatu dan bila ia tidak suka, maka akan berusaha untuk meniadakan atau mengelakkan perasaan tidak suka itu. Jadi, motivasi itu dapat dirangsang dari luar tetapi motivasi itu adalah tumbuh di dalam diri seseorang. Semakin besar motivasi maka semakin besar kesuksesan yang dicapai. Faktor-faktor pendorong disebut juga faktor penyebab kepuasan. Adanya kepuasan akan menambah semangat untuk melaksanakan $\operatorname{aktivitas}^{[6]}$.

Dalam pelaksanaan aktifitas motivasi ini dilakukan dengan mengumpulkan ibu-ibu kelompok Tani Suka Maju dengan memberikan materi mengenai motivasi yang dilakukan oleh pengabdi. Hal ini dilakukan agar ibu-ibu mempunyai semangat untuk berwirusaha sehingga bisa menambah penghasilan. Dari hasil yang diperoleh menunjukkan adanya semangat berwirausaha. Dikarenakan adanya Pandemi Covid-19 selain memberikan motivasi dengan mengumpulkan anggota kelompok Wanita Tani Suka Maju, pengabdi juga melakukan kunjungan ke rumah anggota yang sudah memiliki usaha. Dengan memberikan motivasi dan pendampingan yang berkelanjutan ibu-ibu anggota kelompok tani menjadi semangat untuk selalu mengembangkan produksinya dan selalu berufsaha meningkatkan kualitas produknya. Sehingga masih Perlu pendampingan dan motivasi dari pengabdi. Dalam memberikan motivasi dan pendampingan dilakukan dengan cara selain mengumpulkan anggota juga dengan mendampingi satu persatu anggota yang telah mempunyai usaha[7].

\section{B. Aktivitas Pembuatan Kripik Gedebok Pisang}

Pembuatan keripik gedebok pisang dimulai dengan pemilihan bahan. Bahan baku yang berupa gedebok pisang tidak asal dari pohon pisang tapi yang digunakan adalah pohon pisang kepok. Keripik pelepah pisang ini tidak dibuat dengan bahan baku dari sembarang limbah pohon pisang. 
Untuk menciptakan rasa terbaik, proses produksi hanya menggunakan limbah pohon pisang jenis kapokan atau yang sering dikenal dengan pisang kepok. Pisang jenis ini memang terkenal dengan rasa dan bentuknya yang khas sehingga sering digunakan untuk membuat seriping dan pisang goreng yang enak. Selain itu, jantung dari pohon pisang kepok juga dapat diolah menjadi makanan.

Berikut adalah tahap-tahap kegiatan dalam membuat keripik gedebog pisang[8].

1. Pemilihan gedebog pisang

Tidak semua gedebog pisang bisa dibuat keripik. Hanya beberapa jenis pisang yang "ontong" atau bunga pisangnya bisa dikonsumsi berarti gedebog pisangnya pun bisa dikonsumsi juga. Jenis pisang yang bisa diolah untuk menjadi keripik adalah pisang raja, pisang kapok dan pisang kluthuk.Batangatau gedebog yang digunakan adalah setengah bagian pohon sampai ke pangkal batang / bonggol pisang.

2. Pemotongan

Gedebog dipotong - potong dan dibuang pelepah luarnya yang keras dan berwarna hijau.Ambil bagian pelepah terdalam lalu sisir pinggir pelepah dan sisi luar pelepah.Iris tipis bagian yang berongga kemudian potong-potong kecil sesuai selera.

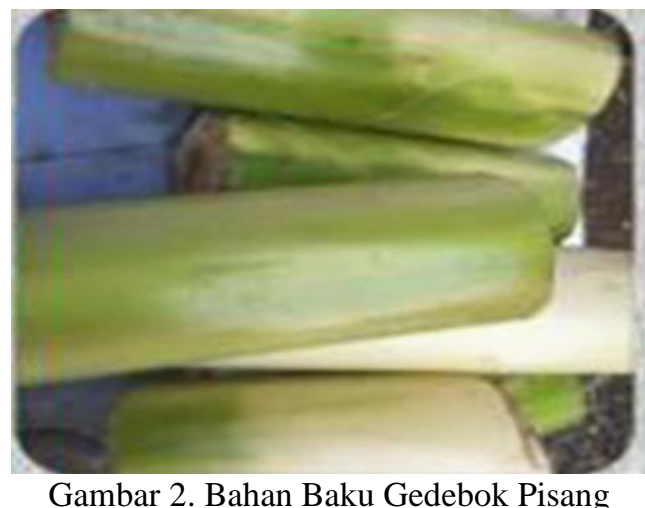

3. Perendaman

Potongan kecil ini lalu direndam air menggunakan campuran garam dan air kapur sirih selama minimal 2 jam. Garam dan air berfungsi untuk mencegah proses "browning" serta mengurangi rasa sepat khas getah pisang.Sementara air kapur sirih berfungsi agar potongan kecil dari gedebog lebih kenyal dan renyah.

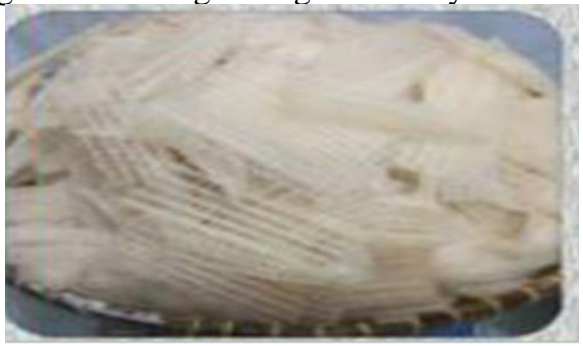

Gambar 3. Gedebok pisang yang sudah dipotong

4. Pencucian

Cuci dengan air mengalir sampai bersih dan sisa air kapur sirih benar-benar hilang.Setelah dicuci lalu diperas sesuai arah serat gedebog pisang.

5. Marinasi

Rendam dengan bumbu kurang lebih 1 jam agar bumbu benar-benar meresap.Untuk bumbunya optional tergantung selera.Bumbu dasar yaitu garam, merica, bubuk kayu manis dan kaldu ayam.

6. Penepungan

Campuran tepung yang digunakan adalah tepung terigu, tepung tapioka dan tepung beras.Apabila menginginkan rasa lebih asin atau gurih lagi campuran tepung ini bisa ditambahkan bumbu dan garam. Potongan kecil gedebog yang telah dimarinasi kemudian di celupkan ke dalam tepung lalu diayak agar butiran tepung yang tidak menempel tidak ikut tergoreng.

7. Penggorengan

Setelah dicelupkankan di dalam campuran tepung, siap untuk digoreng.Pengaturan api harus diperhatikan agar diperoleh hasil keripik yang renyah tetapi tidak berminyak.

8. Pengemasan

Keripik gedebog pisang siap dikemas sesuai selera dan dipasarkan.Untuk varian rasa bisa ditaburkan bumbu instan seperti bubuk balado, bubuk keju, bubuk jagung bakar.

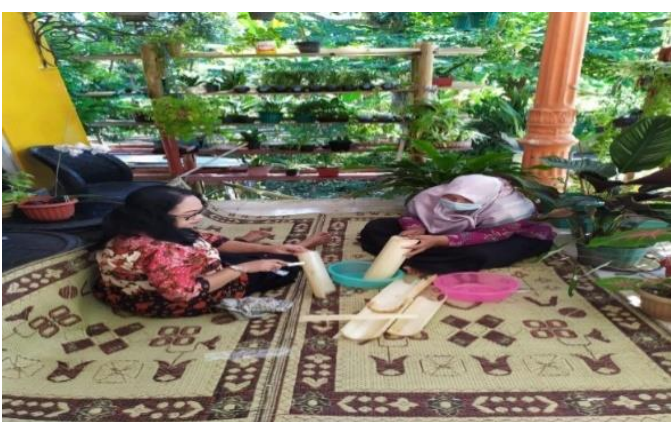

Gambar 4. Aktivitas Pembuatan Keripik Gedebok Pisang

Dengan adanya pandemi covid 19 praktek pembuatan keripik gedebok pisang baru dilakukan tiga kali, hal ini terjadi karena ada pembatasan PPKM sehingga ibuibu kelompok Wanita Tani Suka Maju ada ketakutan untuk berkumpul melakukan praktek pembuatan keripik. Dalam praktek pembuatan sampai saat ini belum menghasilkan produk yang seperti diharapkan karena tepung yang menempel di produk masih terlalu tebal sehingga masih dibutuhkan untuk melakukan beberapa kali praktek pengolahan sampai dengan produk mempunyai kualitas yang baik. Kualitas produk merupakan salah satu point penting bahan pertimbangan konsumen untuk membeli atau 
tidak. Untuk menarik minat konsumen harus bisa menawarkan kualitas terbaik unggulan dari barang yang akan kita jual. Semakin bagus produk, semakin besar pula konsumen tertarik dengan kualitasnya.

Pengertian value added atau nilai tambah adalah usaha pengelolaan barang atau jasa agar bernilai jual. Nilai tambah berperan penting terhadap proses pengambilan keputusan konsumen untuk membeli atau tidaknya suatu produk. Konsep ini juga dapat meningkatkan omset penjualan dan berpengaruh pada kemajuan bisnis. Value added dapat diukur berdasarkan permintaan konsumen dengan hasil berupa kepuasan dari layanan yang diberikan. Terdapat beberapa cara untuk menciptakan nilai tambah yaitu pengembangan teknologi, melakukan inovasi, perbaikan produk dan teknik baru mengahasilan barang.

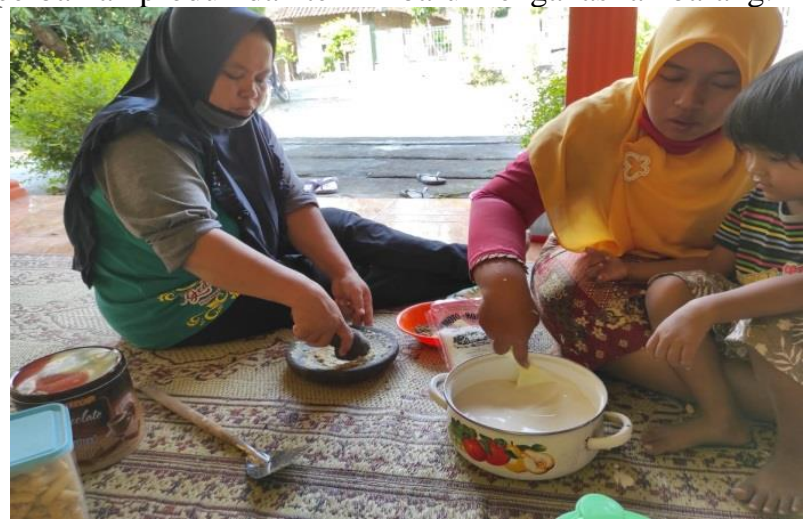

Gambar 5. Aktivitas Pembuatan Keripik Gedebok Pisang

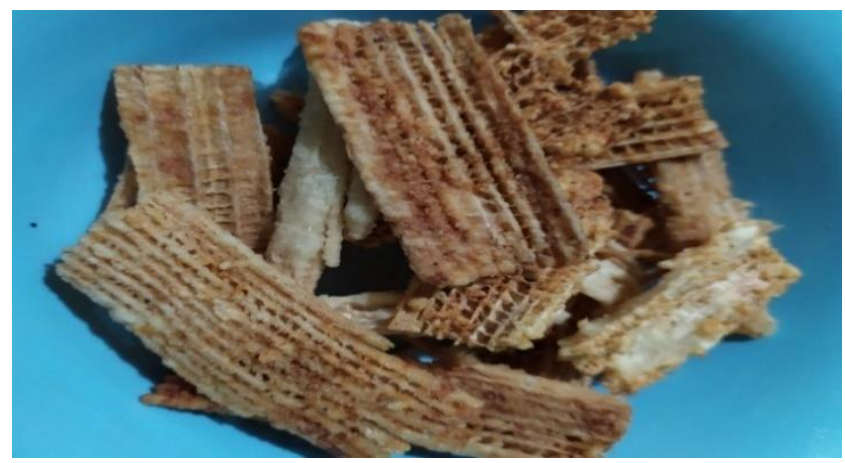

Gambar 6. Hasil Olahan Keripik Gedebok Pisang

Kelompok Wanita Tani Suka Maju mencoba untuk melakukan inovasi dengan memanfaatkan gedebok pisang yang sebelumnya tidak ada harganya setelah diolah menjadi keripik gedebok pisang ini menjadi punya nilai. Dengan berdasarkan informasi online Shopee dapat dilihat bahwa harga keripik gedebok pisang 100 gram dengan harga Rp 10.000,- yang artinya $1 \mathrm{~kg}$ keripik dihargai $\mathrm{Rp} 100.000$., Dengan demikian gedebok pisang mempunyai nilai lebih setelah menjadi keripik.

C. Kemasan yang menarik
Kemasan yang menarik akan membuat minat membeli menjadi lebih tinggi. Sehingga kemasan yang telah dibuat oleh Kelompok Tani Suka Maju perlu diperbaiki agar lebih menarik dan dapat meningkatkan daya jual. Saat ini kemasan hanya menggunakan plastik saja tanpa diberi label. Agar kemasan lebih menarik akan diberi label. Dalam kelompok ini sebenarnya sudah ada beberapa usaha yang dijalankan oleh para ibu-ibu Kelompok Tani, namun belum maksimal dalam pengemasannya. Sehingga masih perlu pendampingan dan motivasi dari pengabdi. Dalam memberikan motivasi dan pendampingan dilakukan dengan cara selain mengumpulkan angggota juga dengan mendatangi satu-persatu yang telah mempunyai usaha. Dengan pendampingan secara personal pengabdi berharap ada semangat dan motivasi dari anggota kelompok untuk semakin rajin memproduksi keripik.

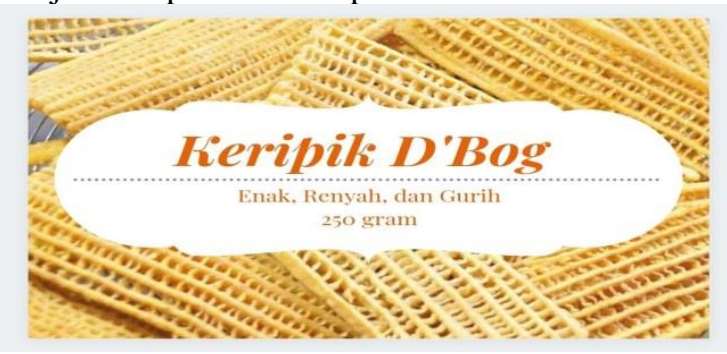

Gambar 7. Label Kemasan Keripik

Gedebok pisang

\section{Pemasaran}

Agar bisnis dapat berkembang pesat, memilih strategi dan teknik pemasaran adalah hal yang sangat krusial $^{[9]}$. Oleh sebab itu, para pelaku bisnis harus menguasai berbagai teknik untuk mengenalkan produk atau layanan secara optimal. Dengan demikian, pemasaran pun dapat terarah dan terfokus dan pada akhirnya memperoleh keuntungan. Melakukan pemasaran adalah hal yang lumrah dilakukan dalam aktivitas bisnis. Namun bila tidak mengetahui tekniknya, pemasaran yang dilakukan pun seringkali tidak tepat sasaran dan menyebabkan kerugian. Oleh sebab itu, penting untuk mengetahui lebih banyak mengenai tekniknya. Teknik pemasaran yang baik dapat menunjang bisnis untuk berkembang dengan pesat dan sesuai perencananaan yang dibuat. Tujuan dari pemasaran yang baik adalah agar produk yang dihasilkan dapat dikenal oleh masyarakat luas, dan tentunya akan meningkatkan potensi penjualan.

Terdapat 5 cara untuk melakukan teknik pemasaran. Hal tersebut bertujuan agar proses pemasaran tidak dilakukan dengan cara biasa, sehingga dapat meningkatkan potensi penjualan. Berikut ini adalah beberapa tekniknya:

1. Melakukan Segmentasi Pasar

Segmentasi pasar merupakan salah satu teknik pemasaran dengan cara mengelompokan pasar sesuai 
dengan jenis kelamin, usia, dan wilayah agar dapat membuat promosi menjadi tepat sasaran. Pemasaran yang dilakukan disesuaikan dengan pengelompokan pasar yang telah dilakukan. Hal yang lumrah bagi para pelaku bisnis dalam melakukan segmentasi pasar. Sebagaimana sebuah strategi dalam teknik permainan, segmentasi pasar pun dilakukan untuk menciptakan produk menjadi pemenang dalam kompetisi bisnis dan juga bisa menguasai pangsa pasar.

2. Perencanaan Produk

Bagian dari teknik pemasaran selanjutnya adalah melakukan perencanaan produk. Hal tersebut meliputi detail produk yang terperinci, pemberian merek produk, pengemasan, serta persediaan produk. Dalam hal ini juga meliputi ikatan emosional antara penjual dan pembeli sehingga memungkinkan pembeli untuk membeli produk tersebut. Melakukan pengenalan suatu produk dapat dilakukan dengan cara diferensiasi produk atau perencanaan produk yang berbeda dari produk lainnya. Hal tersebut bisa berupa pengemasan yang lebih menarik atau juga pelayanan terbaik dalam menerima keluhan.

3. Penetapan Harga yang Sesuai

Hal yang cukup krusial dalam langkah teknik pemasaran adalah penetapan harga produk. Harga disesuaikan dengan kualitas produk dan pasaran kompetitor. Harga yang murah memang diminati oleh konsumen, namun, konsumen juga akan mempertimbangkan kualitasnya. Dengan demikian, jangan ragu menetapkan harga yang mahal selama kualitasnya terjamin.

4. Pendistribusian

Langkah selanjutnya yaitu Pendistribusian. Melakukan distribusi bisa menjalin kemitraan dengan para agen dan distributor agar produk sampai ke tangan konsumen akhir. Dalam proses pendistribusian tersebut pastikan juga jumlah produk disesuaikan dengan wilayah. Wilayah yang memiliki permintaan produk yang tinggi hendaknya mendapatkan kuantitas barang yang banyak.

Setelah produk dihasilkan, maka tentunya akan banyak permintaan terhadap produk tersebut. Dengan demikian, melakukan Pendistribusian akan memenuhi kebutuhan konsumen terhadap permintaan produk tersebut dan tidak ada lagi ketimpangan pemenuhan kebutuhan konsumen.

5. Promosi

Hal yang menjadi inti dalam sebuah pemasaran adalah promosi. Promosi dimaksudkan agar produk yang dihasilkan lebih banyak dikenali oleh banyak orang.
Dengan demikian, bisnis akan dengan mudah untuk mendapatkan calon konsumen baru. Semakin banyak melakukan promosi, potensi untuk meningkatkan penjualan semakin tinggi. Promosi bisa dilakukan di semua media, baik media online atau konvensional guna mendapatkan peluang untuk mendapatkan konsumen dalam jumlah banyak. Dengan demikian, kesempatan untuk mendapatkan keuntungan akan semakin besar. Khususnya pada saat ini, dimana peluang untuk melakukan promosi tersedia di berbagai media. Keberadaan sosial media saat ini sangatlah penting untuk melakukan promosi. Media yang dapat menghubungkan banyak orang di dunia ini merupakan kesempatan untuk mendapatkan keuntungan yang lebih besar melalui memperbesar peluang untuk mendapatkan konsumen ${ }^{[10]}$

Pemasaran yang dilakukan oleh Kelompok Wanita Tani Suka Maju sudah menggunakan media online namun baru sebatas promosi di group whatsaap dan antar teman serta dititipkan di toko-toko. Memang pemasaran merupakan hal yang sulit bagi ibu-ibu anggota Kelompok Tani Suka Maju, mereka bisa memproduksi tapi bagaimana cara pemasarannya, hal tersebut yang sering menjadi masalah bagi anggota kelompok.

Tabel 1

Aktivitas kegiatan Pengabdian kepada Masyarakat

\begin{tabular}{|c|c|c|}
\hline No & Aktivitas & Luaran \\
\hline 1 & $\begin{array}{l}\text { Melakukan } \\
\text { pendampingan dan } \\
\text { pemberian motivasi } \\
\text { terhadap anggota } \\
\text { kelompok usaha }\end{array}$ & $\begin{array}{l}\text { Anggota termotivasi } \\
\text { untuk melakukan usaha } \\
\text { untuk meningkatkan } \\
\text { penghasilan dan } \\
\text { adanya usaha baru yang } \\
\text { dilakukan oleh anggota } \\
\text { kelompok Wanita Tani } \\
\text { Suka Maju }\end{array}$ \\
\hline 2 & $\begin{array}{lr}\text { Melakukan } & \text { Latihan } \\
\text { Proses } & \text { pengolahan } \\
\text { produk } & \text { Hal ini } \\
\text { dilakukan } & \text { dengan } \\
\text { melakukan } & \text { percobaan } \\
\text { pengolahan } & \text { produk } \\
\text { beberapa kali } & \text { untuk } \\
\text { menemukan } & \text { hasil } \\
\text { produk yang berkualitas } \\
\text { baik. }\end{array}$ & $\begin{array}{l}\text { Produk keripik } \\
\text { gedebok pisang yang } \\
\text { dihasilkan semakin } \\
\text { renyah dan tidak cepat } \\
\text { lembek dan minyak } \\
\text { yang terkandung dalam } \\
\text { produk makanan } \\
\text { berkurang. }\end{array}$ \\
\hline 3 & $\begin{array}{l}\text { Membuat label dan } \\
\text { kemasan yang bagus } \\
\text { agar nilai jual semakin } \\
\text { tinggi. }\end{array}$ & $\begin{array}{l}\text { Dengan kemasan yang } \\
\text { bagus diharapkan } \\
\text { penjualan meningkat. }\end{array}$ \\
\hline 4 & $\begin{array}{l}\text { Melakukan workshop } \\
\text { pemasaran secara online } \\
\text { dan secara manual yaitu }\end{array}$ & $\begin{array}{l}\text { Pemasaran secara } \\
\text { online yaitu dengan } \\
\text { menggunakan } \\
\text { whatsaap, Instagram. }\end{array}$ \\
\hline
\end{tabular}




\begin{tabular}{|c|c|c|}
\hline No & Aktivitas & Luaran \\
\hline & $\begin{array}{l}\text { dengan menitipkan ke } \\
\text { warung dan toko. }\end{array}$ & \\
\hline 5 & $\begin{array}{l}\text { Melakukan evaluasi } \\
\text { terhadap hasil kegiatan } \\
\text { kewirausahaan } \\
\text { Kelompok Wanita Tani } \\
\text { Suka Maju }\end{array}$ & $\begin{array}{l}\text { Kegiatan kelompok } \\
\text { berjalan dan banyak } \\
\text { melakukan pelatihan } \\
\text { pembuatan keripik } \\
\text { gedebok pisang. }\end{array}$ \\
\hline 6 & $\begin{array}{l}\text { Melakukan pelaporan } \\
\text { dan analisis terhadap } \\
\text { aktifitas yang telah } \\
\text { dilakukan }\end{array}$ & $\begin{array}{lr}\text { Pelaporan } & \text { kegiatan } \\
\text { selasai } & \text { bulan } \\
\text { November } & \text { dan } \\
\text { kegiatan } & \text { semua } \\
\text { lancar } & \end{array}$ \\
\hline
\end{tabular}

Berdasarkan apa yang telah dilakukan selama lima bulan ini maka ada beberapa hal yang masih harus dilakukan untuk tahapan berikutnya:

1. Melakukan pendampingan dalam hal pemasaran dengan menggunakan media online agar hasil produksinya lebih dikenal oleh masyarakat sehinggal hasil penjualannya lebih meningkat.

2. Pembuatan keripik gedebog pisang ini belum diuji untuk kandungan gizinya, untuk pengabdian berikutnya pengabdi akan mengajak rekan dari Fakultas Biologi sehingga akan mengetahui seberapa besar kandungan gizi yang terdapat dalam keripik gedebok pisang.

3. Melakukan pendampingan dalam pengolahan produk sehingga akan menemukan resep pembuatan keripik gedebok pisang yang reyah, gurih dan enak serta menambahkan varian rasa, misalnya pedas, original atau balado.

4. Selama melakukan pendampingan diharapkan muncul ide-ide dan bertambahnya anggota kelompok yang akan melakukan usaha. Memang ada beberapa anggota yang tertarik melakukan usaha karena dengan adanya Pandemi Covid-19 diberhentikan dari pekerjaannya.

5. Menumbuh kembangkan kreativitas dan prakarsa anggota kelompok UKM untuk memanfaatkan tiap peluang usaha, informasi dan akses permodalan yang tersedia. Hal ini dapat dilakukan dengan meningkatkan kemampuan anggota kelompok untuk melakukan perubahan melalui cara berpikir rasional, efisien, produktif dan banyak anggota kelompok yang akan membuka usaha untuk menambah penghasilan

\section{KESIMPULAN DAN SARAN}

\section{A. KESIMPULAN}

Kesimpulan dari kegiatan pengabdian ini adalah:
1. Pelaksanaan kegiatan yang dilakukan ada beberapa perubahan jadwal pertemuan dengan adanya Pandemi Covid -19. Dikarenakan ada larangan mengumpulkan warga maka waktu pelaksanaan agak mundur namun bisa terlaksana dengan melakukan sarasehan, pemberian materi motivasi dan praktek pembuatan keripik gedebok pisang sampai menemukan rasa yang enak.

2. Penyerapan materi dan praktek yang dilakukan anggota dapat mengetahui bagaimana cara membuat keripik gedebok pisang yang gurih dan renyah.

3. Kemasan dengan menggunakan plastik yang agak tebal dan menggunakan perekat serta sudah diberi label.

B. SARAN

1. Masih diperlukan pendampingan untuk Kelompok Wanita Tani Suka Maju karena masih diperlukan dorongan motivasi untuk bisa berwirausaha.

2. Dengan adanya pendampingan ini diharapkan semakin banyak ibu-ibu yang akan memiliki usaha untuk menambah penghasilan.

3. Menambah jenis produk makanan yang akan dibuat dan dipasarkan

\section{UCAPAN TERIMA KASIH}

Kami mengucapkan terima kasih kepada LPPM yang telah mengakomodasi kami melakukan pengabdian masyarakat dalam Pendampingan Peningkatan Nilai Jual Gedebok Pisang menjadi Bahan Olahan Pangan Kelompok Wanita Tani Suka Maju Kecamatan Kalikotes Klaten.

\section{DAFTAR PUSTKA}

[1] Siswoyo. 2009. "Pengembangan Jiwa Kewirausahaan di kalangan Dosen dan Mahasiswa", I Jurnal Ekonomi dan Bisnis , Vol 10, 2009

[2]Putra. 2020 "PENGERTIAN MOTIVASI: Fungsi, Tujuan dan JenisJenis Teori Motivasi” Februari 6, 2020

[3]Kotler, P. dan Keller, K.L. 2012. Manajemen Pemasaran. Jakarta: Erlangga

[4]Salamadian. Artikel "PENGERTIAN MOTIVASI: Fungsi, Tujuan dan Jenis-Jenis Teori Motivasi" (dapat dia akses di https://salamadian.com/pengertian-motivasi/)

[5]Wikanso. 2013. Pengaruh Pendidikan Kewirausahaan Terhadap Motivasi Berwirausaha Mahasiswa STKIP PGRI Ngawi. Jurnal Ilmiah STKIP PGRI Ngawi Media Prestasi, Vol. XI, No. 1

[6]Hasibuan, M.S.P. 2016. Manajemen Sumber Daya Manusia, Cetakan ke 19, Edisi Revisi. Jakarta: PT. Bumi Aksara.

[7]Astuti,Eka. 2020, Pendampingan Peningkatan Kualitas Produk Olahan Pangan Kelompok Wanita Tani Ngupoyo Boga.Prosiding Sendimas Vol 5 . No. 1.

[8]Cara membuat Keripik Gedebok Pisang. Available: https://carabuatresep.blogspot.com/2020/12/cara-membuat-keripikgedebog-pisang.html (Accessed 1 Mei 2021)

[9]Siswanto, 2009, Pengantar Manajemen, PT Bumi Aksara, Jakarta. 
[10] Cara Pemasaran Produk untuk Penjualan. Available: Posted byAhmat Roihan29 Juni 2020 Marketing https://blog.sribu.com/id/cara-pemasaranproduk-untuk-penjualan/ (Accessed 1 Mei 2021) 